\title{
TREX2 Gene
}

National Cancer Institute

\section{Source}

National Cancer Institute. TREX2 Gene. NCI Thesaurus. Code C20561.

This gene is involved in DNA repair and in the maintenance of DNA integrity. 